\title{
The W Model, a Systematic Engineering for Water Source Clearance, Renewable Energy Production, and Ecological Agricuture Development - A Proposal for Sustainable Development
}

\author{
Tongyuan Wang ${ }^{1}$ \\ ${ }^{1}$ TechEngine plus Com, Canada \\ Correspondence: Tongyuan Wang, TechEngine plus Com, Canada. E-mail: wty70@hotmail.com
}

Received: July 19, 2017

Accepted: August 4, $2017 \quad$ Online Published: September 29, 2017

doi:10.5539/jsd.v10n5p143

URL: https://doi.org/10.5539/jsd.v10n5p143

\begin{abstract}
This article proposes a systematic engineering for sustainable economic and ecologic development. This system is deemed to be applicable in any country of the world. The system aims to realize five important objectives: water source clearance, energy saving and emission reduction, renewable energy and organic fertilizer production, and ecological agriculture development, all in large scale and at low cost. The main conception of the new system to reach these goals is the replacement of the conventional sewage treatment approach with more efficient and more ecological process - the natural fermentation of the mixture of the urban sewage and agrarian wastes, such that water body clearance, including water de-eutrophication, green algae prevention and siltation dredging will all be accomplished at virtually a zero cost. Along with this process, the system can produce a vast amount of renewable energy and organic fertilizers, consequently ecological agriculture development in large scale can be realized. As a result, this system will greatly reduce the use of chemical fertilizers thus largely reduce the consumption of fossil energy and the related polluting emissions. This system is thus fully a circular economy model through full west-reuse processes, which ultimately will enhance our life quality with healthier food and living environment. The system is flexible and adaptable to be implemented in either small towns or megacities. The implementation and operation of this system will also benefits employment growth. Lastly, in terms of economic feasibility and profitability, millions to billions of dollars of annual revenue can be generated from the running of this system in a country.
\end{abstract}

Keywords: systematic engineering, water source clearance, renewable energy, organic fertilizer, ecological farming, sewage treatment, circular economy, green economy, waste reuse

\section{Introduction}

The $\mathrm{W}$ model refers to a systematic engineering presented in this paper for water source clearance, renewable energy and organic fertilizer production, and economical agriculture development (hereafter "the system", "the program" or the "solution"). This system is the result of a multiple-year study independently undertaken by the author. This system aims to protect and enhance supplies of the three most indispensable resources for human beings: clean water, renewable energy and healthy food. More importantly, these goals are to be realized through a revolutionary change of the conventional non-ecological urban sewages process technique into an environmental intimate approach at low cost. This system thus would bring great environmental, social and economic benefits to our society.

The inputs of this system are fully wastes, including urban sewages and agrarian wastes. The urban sewage as mentioned above and hereunder is a generalized notion, and it includes various effluents from households, sugar mills, breweries, food plants, slaughterhouses, and so on (but excluding those from chemical or heavy industries). The agrarian wastes include various post-harvest crop stems, leaves, grasses, unusable vegetable parts, fruit peels, livestock waste and bones, etc. Meanwhile the process of soluble and perishable garbage could fully be integrated into this system (the related new approach for urban garbage collection, sorting, transportation and processing can be presented separately upon request). The (generalized) sewage is taken to be the main source of nitrogen and phosphorous nutrient pollution to the waterways running along most of the cities over the world. The system thus could deter and hold most (if not all) of the nutrients from sources outflowing into the water bodies (rivers, lakes, etc.). In this way, a vast amount of renewable energy - biogas and organic fertilizers can be 
produced from the system. The system implementation is cost effective and investment profitable. Billions of dollars of revenue can be generated from this system each year in an average country. Consequently, ecological farming and agricultural development in large scale can be realized, because of the availability of abundant organic fertilizer which can largely save the use of the chemical fertilizers. At the same time, waterway clearance could be realized with a zero cost, since there is no source of sewage or waste to be discharged into the water source any longer, and since the revenues generated from the system can be more than covering the costs of implementing and running the system. This is an important concept, since in this report, the notation "water source clearance" includes water de-nutrition, green alga prevention and siltation dredging, it is very costly to solve all of these problems nowadays. In all, the system provides an integrated and effective solution for those difficult but seemingly isolated problems today, such as urban and rural perishable waste disposal, animal bones handling and waste material reuse. The implementation and running of this system also helps employment increase as can be seen later.

The following sections elaborate the above summaries. The second section describes briefly the background and the main sources of nutrient pollutants to water bodies. The third section presents the general scheme of the system and technology to be used. The fourth section summarizes the benefits and significances to implement and run this system. The fifth and sixth sections present economic and technical feasibility analysis of implementation of this system respectively. The seventh section describes the approach to start this program by way of a pilot project. The last is a brief conclusion.

\section{The History, Issues and Challenges}

As can be understood, the goal of sustainable development is to maintain and improve human life quality not only presently but more importantly for our future generations. The very basic life quality is embodied in the qualities of our daily three intakes: water, air and food. A bad news is that these qualities are not upgrading but rather degrading in the last few centuries, although technologies have been advanced a lot in this period of time. Here we briefly look into why these qualities get degraded starting with the water source pollution first.

There are various pollutants to water sources, yet worldwide precise analysis of the pollutant percentile contributions to the water pollution is not much available. In a general observation and in terms of the volume, the urban sewage discharges should be seen as the first main source of the pollution, followed with agricultural runoffs, urban garbage, and so on. Waste discharges from chemical and heavy industrial mills are certainly other serious sources, which, however, will be discussed in other paper. Now we look at the sewage problem first.

In a typical agrarian age, people farm, seed and fertilize crops, and after harvest we consume grains, fruits and vegetables. Then we reuse human and livestock manures to fertilize the crops again. These form a natural and ecological cycle of farming and food production for our human society (Fig.1).

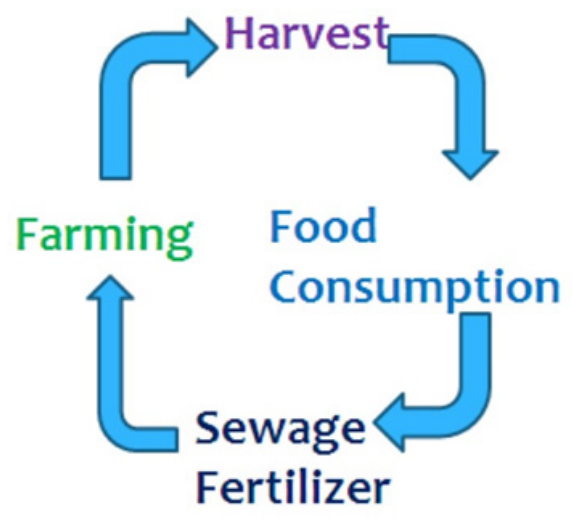

Figure 1. The ecological cycle

However, in the urbanization age, especially in the modern era of post-industry, a large population lives in cities (either metropolitans or towns) as major consumption centers of various foods and fruits, but human and livestock manures as well as other organic wastes are no longer returned to the farmland as fertilizer but discharged into rivers, lakes or other water bodies. That is, the natural cycle of Fig. 1 is broken (see Fig. 2), which consequently causes a series of problems, while the worst thing is the piecemealed solutions to these problems. 


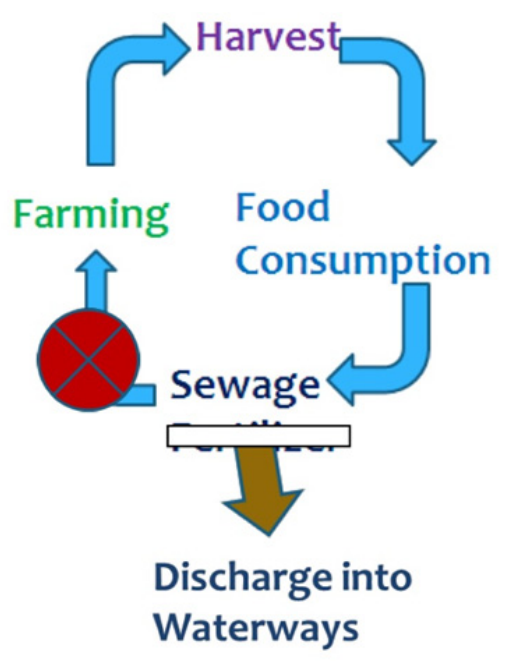

Figure 2. Ecological cycle destruction

Firstly, a large volume of sewage discharge will pollute the containing water bodies. The conventional solution for this is to build sewage processing plants, including the use of chemicals to remove nitrogen and phosphorus nutrients and other COD (chemical oxygen demand) contents. This approach however, inevitably leaves chemical residuals in the water bodies and causes another sort of pollution. Secondly, the nutrients by no means could be completely filtered out, and the water bodies are eventually enriched with nutrients (called eutrophication), and consequently leads to green algae booms and water becoming undrinkable. People then try to find other means and facilities to further extract nutrients and to get rid of green algae, etc. Thirdly, the processed sewage is still discharged into water bodies finally. The discharge in large scale of sewage (processed or not) ultimately sediment and silt up waterways. Even though a number of approaches and projects have been tried in many places to solve the eutrophication, the algae and the sedimentation problems [11][26][43], such projects are unavoidably costly, laboring, and incompetent in many cases, This can be reflected from the fact that many streams, rivers and lakes in or outside of many cities in the world no longer exist. These kinds of problems present worldwide, in either developing or developed countries. For example, in spite of many local efforts to improve water quality [14], there was a report [28] of serious water pollution problem in the Lake Winnipeg of Canada. We notice that a number of advanced researches have been undertaken to improve or to replace the conventional sewage treatment approach. One of the examples is the microbial fuel cell (MFC) approach, which makes use of the biochemical effect of anaerobic bacteria digestion of the sewage to generate electricity. However, this kind of approach is subject to temperature and other technical conditions thus could not be feasibly implemented for large scale commercial use at least in the near future in terms of both cost and efficiency [2][3][22][37]. At the same time, a problem remains but largely ignored from this approach is where and how to dispose the large amount of the final residues.

The above tells that we have been trying to wipe out the nutrients from the sewage filled waters by all means, but on the other hand we need those nutrients to fertilize the crops in the farmland to meet the consumption needs of the large urban population. How to meet the fertilizer demands then? The conventional solution is to build fertilizer plants to supply chemical fertilizers. Now farmers are largely relying on the chemical fertilizer supplies, again in either developing or developed countries [42]. As a reference, the world average consumption of chemical fertilizer nutrients $\left(\mathrm{N}+\mathrm{P}_{2} \mathrm{O}_{5}+\mathrm{K}_{2} \mathrm{O}\right)$ is increased from $114.4 \mathrm{~kg}$ in 2004 to $133.5 \mathrm{~kg}$ in 2011 per hectare arable land [19][24], and this increasing trend will be continued at least in near future [15].

What is wrong to use the chemical fertilizers? As we all know, chemical fertilizer leads to soil acidification and compaction. The more the use of chemical fertilizers, the more degraded becomes soil fertility, thus additional fertilizers are needed to gain high corn productions. This implies a vicious circle. Note also that soil pollution is more difficult to control and recover than is water pollution. At the same time, the abundant use of chemical fertilizers such as urea or ammonia would become a main source of the nutrient pollutants of agricultural runoffs. A simple reason for this is that nitrogen or phosphorous contents of the chemicals are far more soluble than those from soil or compost fertilizer. In a special case, if an application of chemical fertilizer were followed immediately with a storm or rain, then a big portion of the nutrients from the chemical fertilizers would be seized and brought to the waterways by the rain flow. This is why the agrarian runoff has been becoming another main source of nutrient pollution as mentioned before. Furthermore, the field application of the nitrogen fertilizer is one of the main sources of haze as revealed in a recent study that the reaction of ammonia released from this 
fertilizer with impurities in the air forms PM2.5 particles [45]. Even worse, the production of chemical fertilizers contributes a lot to environmental pollution while consuming a big amount of natural resources: First, a chemical fertilizer plant is a large source of pollution, because of its dense waste air emissions and waste water discharge, including residual nitrogen or phosphorous contents from the respect fertilizer plants. Secondly, a fertilizer plant is usually a large energy-consumer. This is due not only to the production process itself consuming a lot of energy, but also the input material required for the production. This is particularly true in the production of nitrogen fertilizers wherein a large amount of energy substances such as natural gas or coal gas needs to be the raw input material for ammonia synthesis, which in turn further aggravates the energy shortage problem in the world.

What described above seems more than a little absurd: on one hand we try every means to destroy or eliminate nitrogen or phosphate nutrient from our own life wastes, but on the other hand we try to produce as much as possible these same nutrients through various chemical fertilizer plants. This contradiction implies that our life style, production mode and the waste treatment approach after the industrial revolution need to be reexamined, at least, the said style and mode make the already complex world more complicated. As such, we need to find a new solution to the above problems such that the complicated world could turn back to its simplicity, and the key point is to get the ruined natural and ecological cycle to be recovered.

\section{The Proposed New Solution}

If we say that industrialization and urbanization is the root of pollution and the main cause of destruction of the natural ecological cycle, the modern technology and capital strength on the other hand are fully capable of overcoming pollution and restoring the ecological cycle. The main problems are two, do we people, especially the politicians, wealth/capital holders and governments over the world really want to change the mentioned life styles and production-waste-treatment approaches, and if we do, how to realize the changes in terms of engineering technologies? This paper mainly discusses the latter, particularly on sewage treatment approach. In this regard, an important notice here is, what people have tried so far is only to deal with the sewage itself, rather than on how to restore the natural cycle. Based on this insight, the solution to be presented in this article is a systemic sewage process program aimed to restore the natural ecological cycle as depicted in Fig.3.

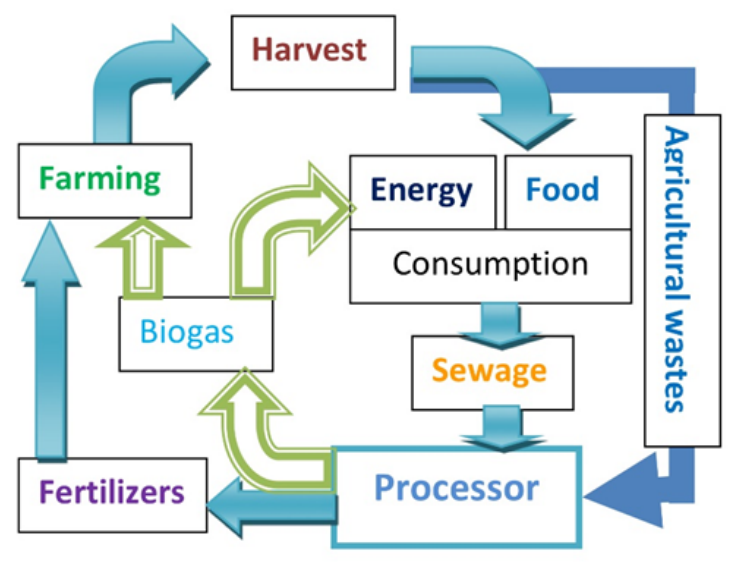

Figure 3. Recovered and enhanced ecological cycle

The core idea of this program is: abandon the conventional chemical process approach, and (the generalized) sewage is no longer directly or indirectly discharged into rivers or other water bodies, but drained directly to a number of processing stations spreading over outer suburbs (rural or farmland) through a number of pipelines,. In each processing station agrarian wastes and rural sewage are collected and mixed into the urban sewage so as to produce methane and organic compound fertilizers thereafter through a natural biological fermentation process. In this way, there will be no longer any leftover from this system to discharge into water bodies, since the organic fertilizer produced (either in solid or liquid state) can be fully used locally in areas surrounding each processing station for farming, aquiculture or other purposes.

In the above way, urban sewage as a trouble matter now becomes a treasure, and so do rural wastes and animal remains. For instance, the dead pigs, birds and poultries in an avian-influenza period or other situation could be fully collected and processed within this system. This way will save the use of biochemical facilities to keep and process such animal bodies, notice that once such a biochemical process facility is built up, it requires maintenance even if no job to do. Similarly, the problem of post-harvest crop straws can be well solved in this 
approach. Although a number of practices and studies on how to make use of those crop straws more commercially, for instance, to produce ethanol and the like bio-hydrogen gas [17][40], have been attempted, those approaches could not be widely implemented due to the issues of cost effectiveness and how to dispose the process residuals. Up to date, in many places those straws are simply burned in the field after the harvest, which induces serious air pollution and smog problem. For instance, the Environmental Protection Department of China had reported that straw burning is one of the main causes of the smog in the northeast part of China [52].

From the above, we can see that the proposed system and solution is a one-stone-multiple-birds approach. The first significance of this approach as shown in Fig. 3 is the broken ecological cycle will not only be restored but also be enhanced and enriched. The practical significance is the establishment of a fully circular economy by way of full waste-reuse, and large-scale biological/organic agriculture development [30][35] become realizable. These will be further analyzed in the next sections.

In view of implementation, the system will be featured with the following:

3.1) Divisibility: For a city and its suburbs, the implementation of this system can be done in one time, or divided into a number of parts or different phases. Integration of the differently phased or partially done projects could be easily performed, as long as an appropriate overall design and implementation plan is made.

3.2) Updatability: The system goals can be achieved through a basic (or primary) implementation through to advanced realization. For instance, the primary goals can be mainly for environmental protections including sewage process, water body clearance and fertilizer production. The advanced goals would include the biogas production and the related process optimization.

3.3) Extensibility: For example, methane purification, liquefaction, and the use of the methane for industrial raw materials, for electricity power plants, and other applications.

3.4) Environmental intimacy and long term sustainability: Compared with the energy production of fossil resources, the biogas (methane as its main content) and organic fertilizer produced from this system is fully from the wastes of human life, and the production can be in endless loop without any damage to the environment or an exhaustion of natural resource.

3.5) One-time solution: Through this program, both urban and rural sewage and soluble waste issues will be completely resolved once and for all, thus the goal of water body clearance and ecological agriculture will be consequently approached. Notice again, the water body clearance including algae removing, sludge dredging and other related work, each of them being conventionally expensive to implement time by time, now will be realized with virtually zero cost and lasting for long.

3.6) Combinability with other infrastructure constructions: This system can be built up with companion(s) of, for instance, a gas network, road network and rural transportation constructions or reconstructions, such that the total cost of these constructions could be optimized and reduced. More benefits are described in the next section.

\section{Benefits and Significances}

The above sections have given an overall description of the advantages and benefits brought by the proposed system. More detailed and quantitative analysis is given below.

\subsection{Measurable physical outputs}

To give a numerical illustration, we take a city of 2.5 million residents as an example, and assume its annual sewage disposal to be 100 million cubic meters $\left(\mathrm{m}^{3}\right)^{1}$ based on a conservative estimate of $40 \mathrm{~m}^{3}$ per person per year. From this source, about 0.75 billion cubic meters of biogas (in a purity of $95 \%$ methane to be calculated, in order for it to be comparable with the natural gas) and 8 million tons of (dry) organic fertilizers (composts), in addition to nearly 100 million cubic meters of nutrient enriched water, are expected to be produced annually. Note that the said volume of the biogas to be produced is not the most optimistic but a rather conservative estimate. The methods used for all the estimations here and hereunder can be found in the appended Table A.

The above estimates and the numbers are simple, but the significance and the benefits implied are astounding, as described below.

4.2 Abundant renewable energy source and production: It is no exaggeration to say that the approach to produce the renewable energy - methane - from this system is more advantageous than those popularly known approaches, for instance, wind energy, solar energy, and bio-fuels made from corns or sugar canes, etc. Wind

\footnotetext{
${ }^{1}$ Note that this estimated amount is based on the assumption of the separated drainage system. That is, the natural rain flow is not mixed with the "sewage" water flow to drain together. If they are mixed, the amount would be much larger.
} 
energy is unstable and not cheap. Solar energy is a bit more reliable than wind energy but still unstable. Additionally, although solar energy is clean, the production of the solar wafers (to gather solar energy) is contaminative, while low pollution wafer production is costly to date. Using corn or sugar canes to produce ethanol and similar bio-fuels consumes food sources and requires a vast farmland to grow the requisite corn or canes. The renewable energy, methane, produced from this system is not only from an abundant and continuous source (of the sewage) without a worry of exhaustion, but also produces virtually no pollution, offers no side effects in the production, and comes at a zero net cost if it is taken to be a byproduct of sewage process.

Now, let us see the amazing volume of the biogas that can be produced from this system. From paragraph 4.1, a city of 2.5 million people can obtain 0.75 billion cubic meters of methane (similar to natural gas as given before) per year. As the total urban residents of the world are over 3.7 billion [1], and if this system is implemented worldwide, more than 1 trillion cubic meters of methane can be produced annually, which represents $1 / 3$ of the total volume of the natural gas produced in the world in 2002 [10]. Note this ratio could be over $100 \%$ if energy saving is considered with the production of the fertilizer together as seen in the next paragraph. Particularly, this ratio could be over a few folds for countries poorer in energy resources especially in natural gas (refer to Table 1 below).

4.3 Energy saving and emission reduction: Here we use the production of organic (compost) fertilizer to see the effects brought from this system. Again for the city of 2.5 million residents, 8 million tons of dry organic fertilizer can be produced annually. Suppose each ton of the fertilizer holds nitrogen-ammonia $\left(\mathrm{N}+\mathrm{NH}_{3}\right)$ in $6 \%$ (of weight) only, which in whole equals to the same $\mathrm{N}$ contents of 1 million tons of chemical fertilizer (urea-46\%). That is, an implementation of this system in the said city can save a urea plant of a million-ton annual production capacity. This saving also implies a saving of the production of ammonia required to produce the urea. The total energy material savings for the production of the said amount of urea and ammonia would come to be 5 billion cubic meters of natural gas. In other words, if we take the saved energy as an added energy production, the renewable energy production stated in 4.2 should be increased several folds. If this amount of natural gas is replaced with coal as raw material, then it is more than 5 million tons of crude coal a year. Note this saving does not include the energy saving for the production of other nutrients contained in the composts.

Take it more conservatively and assume only a half -2.5 billion $\mathrm{m}^{3}$ - of the natural gas to be saved, which is equal to 2.25 million tons oil equivalent (TOE) [10] of coal each year from the said city of 2.5 million residents. In this way 3.3 billion TOE of coal can be saved annually, more than $80 \%$ of the coal produced globally [10] in 2012 as shown in Table 1. Furthermore, this amount of saving equals to $500 \%$ of the nuclear power produced in the world [10] in 2012, while the safety issue of nuclear energy production is always concerned by all of us.

In terms of emission saving, the above could lead to a conclusion that up to 30 billion tons of carbon-emission can be reduced each year worldwide (see Table A, item 10). This is of particular significance today for the goal of mitigation of air pollution and climate change.

For an easier understanding, the various effects especially in energy savings from this system globally and in some example countries are summarized in Table 1. From this table, we can get a number of interesting implications. For instance, for natural resource rich countries, such as Canada and US who assume the lowest or lower estimated increase ratios of urea and NPK total and in energy saving brought by this system, which reflects the fact that these rich countries have consumed (also produced and exported) the fertilizers and energy in higher degree (per capita, similarly hereunder) than other countries [42], thus would assume more pressure in resource consumption and environmental protection. On the other hand, in average, especially for resource poorer countries, either developing or developed, the benefits from implementing and running this system is substantially significant as can be seen from Table 1 .

4.4 Water source protection and clearance, environmental benefits: These were stated before and should now be obvious to see. Since sewages and other perishable wastes are not to be discharged into waterways any longer, most (if not all) of the concerned environmental problems, such as water eutrophication, algae breeding, siltation of the waterways, will be automatically overcome with no extra cost.

4.5 Flood prevention (to some degree): Flood is a common natural disaster to many urban citizens in some seasons. Why and how can this system play a role in flood control or prevention? It is simple: every outlet pipeline of this system from the city below the flood-warning level can be temporarily used as a spillway in the case of flood. Of course, this spillway function varies city by city, depending on the topography and other circumstances of a particular city, but the conventional sewage treatment approach could not play this role at all. 
Table 1. Expected results and effects brought by the system

\begin{tabular}{|c|c|c|c|c|c|c|c|}
\hline Items & $\begin{array}{l}\text { A } \\
\text { city }\end{array}$ & Canada & U.S. & Japan & China & Brazil & Globally \\
\hline Population (millions) & 2.5 & $28(35.3)$ & $256(316)$ & $116(127)$ & $800 *(1357)$ & $167(196)$ & $3711(7137)$ \\
\hline $\begin{array}{l}\text { Dry fertilizer (million } \\
\text { MT) }\end{array}$ & 8.0 & 90 & 797 & 371 & 2560 & 534 & 11875 \\
\hline $\begin{array}{l}\text { Urea equiv. (million } \\
\mathrm{MT} \text { ) }\end{array}$ & 1.05 & 12/1.1 (10.9) & $\begin{array}{l}107 / 2.6 \\
(41.1)\end{array}$ & $\begin{array}{l}49 / 0.01 \\
(4900)\end{array}$ & $\begin{array}{l}336 / 23 \\
(14.6)\end{array}$ & $\begin{array}{l}70 / 1.8 \\
(39.0)\end{array}$ & $1559 / 60(26.0)$ \\
\hline $\begin{array}{l}\text { N.P.K. equiv. (million } \\
\text { MT) }\end{array}$ & 0.8 & $9 / 3.4(2.8)$ & $80 / 20(4.0)$ & $37 / 1.0(37)$ & $256 / 51(5.0)$ & $53 / 12(4.4)$ & $119 / 176(6.8)$ \\
\hline $\begin{array}{l}\text { Primary energy equiv } \\
\text { (million toe) }\end{array}$ & 2.25 & $25 / 329(8 \%)$ & $\begin{array}{l}230 / 2209 \\
(10.4 \%)\end{array}$ & $\begin{array}{l}104 / 478 \\
(21 \%)\end{array}$ & $\begin{array}{l}720 / 2735 \\
(26.5 \%)\end{array}$ & $\begin{array}{l}144 / 275 \\
(50.2 \%)\end{array}$ & $\begin{array}{ll}3340 / & 12477 \\
(27 \%) & \end{array}$ \\
\hline $\begin{array}{l}\text { Direct natural Gas } \\
\text { Saving (billion m3) }\end{array}$ & 0.75 & $8.4 / 156(0.054)$ & $\begin{array}{l}77 / 681 \\
(0.115)\end{array}$ & $35 / * *$ & $\begin{array}{l}240 / 107 \\
(2.24)\end{array}$ & $50 / 17(3.00)$ & $\begin{array}{l}1113 / \\
(33 \%)\end{array}$ \\
\hline $\begin{array}{l}\text { Grand NG Saving } \\
\text { (billion } \mathrm{m} 3 \text { ) }\end{array}$ & 2.5 & $28 / 156(0.18)$ & $26 / 681(3.8)$ & $117 / * *$ & $\begin{array}{l}800 / 107 \\
(7.47)\end{array}$ & $\begin{array}{l}167 / 17 \\
(10.00)\end{array}$ & $\begin{array}{ll}3704 / & 3363 \\
(110 \%) & \end{array}$ \\
\hline $\begin{array}{l}\text { Coal Savings (million } \\
\text { toe) }\end{array}$ & 2.25 & $25 / 35(71 \%)$ & $\begin{array}{l}230 / 516 \\
(45 \%)\end{array}$ & $\begin{array}{l}104 / 0.7 \\
(15000 \%)\end{array}$ & $\begin{array}{l}720 / 1825 \\
(39 \%)\end{array}$ & $\begin{array}{l}144 / 2.2 \\
(6600 \%)\end{array}$ & $\begin{array}{l}3340 / \\
(88 \%)\end{array}$ \\
\hline Oil equiv. (million MT) & 2.25 & $25 / 183(13.7 \%)$ & $\begin{array}{l}230 / 395 \\
(58 \%)\end{array}$ & $104 / * *$ & $\begin{array}{l}720 / 208 \\
(350 \%)\end{array}$ & $\begin{array}{l}144 / 112 \\
(129 \%)\end{array}$ & $\begin{array}{l}3340 / 4119 \\
(80.1 \%)\end{array}$ \\
\hline $\begin{array}{l}\text { Nuclear energy equiv } \\
\text { (million toe) }\end{array}$ & 2.25 & $25 / 21(80 \%)$ & $\begin{array}{l}230 / 183 \\
(126 \%)\end{array}$ & $\begin{array}{l}104 / 4.1 \\
(2500 \%)\end{array}$ & $\begin{array}{l}720 / 22 \\
(3270 \%)\end{array}$ & $\begin{array}{l}144 / 3.6 \\
(4000 \%)\end{array}$ & $\begin{array}{l}3340 / \\
(500 \%)\end{array}$ \\
\hline $\begin{array}{l}\text { Renewable energy } \\
\text { equiv (million toe) }\end{array}$ & 2.25 & $25 / 4.3(600 \%)$ & $\begin{array}{l}230 / 51 \\
(460 \%)\end{array}$ & $\begin{array}{l}104 / 8.2 \\
(1270 \%)\end{array}$ & $\begin{array}{l}720 / 32 \\
(2250 \%)\end{array}$ & $\begin{array}{l}144 / 11 \\
(1300 \%)\end{array}$ & $\begin{array}{ll}3340 / & 237 \\
(1420 \%) & \end{array}$ \\
\hline $\begin{array}{l}\text { Hydroelectricity equiv. } \\
\text { (million toe) }\end{array}$ & 2.25 & $25 / 86(30 \%)$ & $\begin{array}{l}230 / 63 \\
(365 \%)\end{array}$ & $\begin{array}{l}104 / 18 \\
(580 \%)\end{array}$ & $\begin{array}{l}720 / 195 \\
(370 \%)\end{array}$ & $\begin{array}{l}144 / 95 \\
(1516 \%)\end{array}$ & $\begin{array}{l}3340 / \\
(402 \%)\end{array}$ \\
\hline $\begin{array}{l}\text { Fertilize \& water land } \\
\text { (million ha) }\end{array}$ & 0.16 & $1.8 / 0.79(228 \%)$ & $\begin{array}{l}16 / 22.3 \\
(72 \%)\end{array}$ & $7.0 / 2.6(27 \%)$ & $\begin{array}{l}52 / 54.5 \\
(96 \%)\end{array}$ & $\begin{array}{l}11 / 2.9 \\
(38 \%)\end{array}$ & $\begin{array}{l}222 / \\
(70 \%)\end{array}$ \\
\hline $\begin{array}{l}\text { Crops produ. Increase } \\
\text { (million MT) }\end{array}$ & & $33 / 53(63 \%)$ & $\begin{array}{l}371 / 353 \\
(105 \%)\end{array}$ & $\begin{array}{l}156 / 12 \\
(1300 \%)\end{array}$ & $\begin{array}{l}762 / 544 \\
(140 \%)\end{array}$ & $\begin{array}{l}108 / 91 \\
(119 \%)\end{array}$ & $\begin{array}{ll}6200 / & 3049 \\
(203 \%) & \end{array}$ \\
\hline
\end{tabular}

Notes:

The 2nd column is the data of the example city given in the text, all other estimates assumed to be linear to the urban population based on the example data.

Population data is from reference [1] and expressed in urban/total (percentage). * Chinese urban population estimated for near future due to its rapid increase.

The 4th row gives estimates of the equivalent nitrogen nutrient (not gross) tonnages (the number before the slash) from the dry fertilizer, compared with the/real nutrient amount [24] consumed in each country (after the slash). The number in the parentheses is the ratio of these two numbers.

Similarly, the 5 th row shows the comparisons of the equivalent total nutrient $(\mathrm{N}+\mathrm{P} 2 \mathrm{O} 5+\mathrm{K} 2)$ tonnages of the dry fertilizer with the/real nutrient amount [24] consumed in each country.

The 6th row presents the total (primary) energy (materials) to be saved to produce the amount of dry fertilizer compared with the real primary energy consumed in 2012 [10], and expressed in estimate/real consumption (percentage).

From row 7 to 12 are the equivalences of different energy (materials) to be saved to produce the amount of dry fertilizer compared with the real data from [10], where natural gas coal and oil are productions while others are consumptions. The expression format: estimated saving /real current data (percentage or folds), where 1 billion $\mathrm{m} 3$ of natural gas $=0.9$ million tonnes oil equivalent (toe) $=1.27$ million ton of coal [13]. ** Japan's data is negligible and not shown on [10].

The last (13th) row shows the potential increases of crop productions due to the increase of the amount of the fertilizer hence the total increased nutrients to be produced from this system, assuming cropland and other factors not changed. The numbers before and after the slash is the estimated net increase and /the real crop productions in 2012 [18], followed by the percentage of the increase. E.g., in the last cell, the increase rate $203 \%=(6.8$ (from the 5 th row) -1$) * 0.35 \%$ (the elasticity $\mathrm{S}$ given in paragraph 4.8$)$. Here the crops includes various cereals, beans, oil seeds, etc., but excludes potatoes, sweet potatoes, fruits and vegetables. 
The following paragraphs describe the benefits and significance of this system more particularly for ecological agriculture development and quality crop production.

4.6 A large amount of organic fertilizer and nutrient water to fertilize the cropland and to prevent soil degradation. In either the so called ecological or organic farming [30][35], the first requirement is the supply of large volume of organic fertilizer compared with other factors, e.g. the mitigation of the use of insecticides, etc. From 4.1, for a city of 2.5 million people, each year this system can produce 8 million tons of dry organic (compost) fertilizer and 100 million $\mathrm{m}^{3}$ of nutrient rich water, which can fertilize more than 0.16 million hectares of cropland, such that 50 tons of the dry fertilizer and $600 \mathrm{~m}^{3}$ of nutrient water (in addition to the natural rainfall) can be applied to each hectare annually. How significant does this mean? It means the system virtually fully solve the fertilizer and watering problem for farming. Take the 50 tons of the dry compost as an example, and as assumed before it contains $6 \%$ nitrogen and ammonia, which gives more than $600 \mathrm{~kg}$ standard urea per hectare. This is near five times of the nitrogen chemical fertilizer averagely used today in the world (refer to Section 3 and reference [19]). In this scale and take it worldwide again, this system can fertilize and water 222 million hectares of the cropland, which equals about $70 \%$ of the irrigated land (of 326 million hectares) in the world [29], and the problem of soil degradation thus can be overcome or at least abated. In this regard, it is reported [50] that nearly a total of 2000 million hectares of land in the world were degraded, of which 910 million hectares to at middle degree and 305 million hectares to serious or extremely degree (no longer suitable for agriculture). As can be seen the sum of the two is almost about $90 \%$ of the area of the arable land (of around 1,400 million hectares) in the world [5]. The soil degradation issue is critical for many developing countries especially for a long term view. On the other hand, developed countries are not exceptional, and it is worthwhile to look at reference [20] and see the importance and significance to prevent soil degradation:

"Iowa has lost more than half of its fertile topsoil after farming there for about 30 years. Their topsoil is being lost about 30 times faster than sustainability."

Additionally, note that the composts produced from this system can be used not only for agriculture, but also for foresting, green work, horticulture and household flowering, etc.

4.7 Drought resistance: If the flood-prevention function stated in 4.5 is mainly beneficial to urban citizens, then the drought-resistance function of this system benefits the farmers for crop watering. This functionality has just been stated in the above paragraph about the large volume of nutrient rich water and its use. In this regard, recall that even the strongest country in the world, the U.S., could not do much to combat the serious drought and its impacts on crop production occurring in 2012, for example. We can thus see the benefit and significance of the implementation of this system to agriculture again.

Table 2. Global Fertilizer use and cereals yields

\begin{tabular}{llll}
\hline Items & 1930 & 1975 & 1999 \\
\hline Total nutrients (N, K2O, P2O5) in million tons & 5.5 & 91.1 & 140.4 \\
Av. yield cereals, t/ha & 1.1 & 2.0 & 3.3 \\
\hline
\end{tabular}

4.8 Improvement of food supply in general and organic and safe food supply in particular: This is a logical implication and outcome of the previous paragraphs. Numerically the potential increase of the crop productions due to the increase of the amount of the fertilizer is impressive.

According to [42], $40 \sim 60 \%$ of increase of crop production can be attributed to the increase of fertilizer applications. Here we take the lower bound $40 \%$ in the following analysis. The reference [42] also provided related data shown in Table 2. Based on these data we can use the "elasticity"

$\mathrm{S}=$ percentage of yield increase / percentage of fertilizer increase

to describe the relation of these two increases, and take only $40 \%$ crop yield increase to be attributed to the increase of the fertilizer use.

$$
\begin{aligned}
& \mathrm{S}_{1930-1975}=((2.0-1.1) / 1.1 * 40 \%) /((91.1-5.5) / / 5.5)=0.33 / 15.56=0.0212 ; \\
& \mathrm{S}_{1975-1999}=((3.3-2.0) / 2.0 * 40 \%) /((140.4-91.1) / / 91.1)=0.26 / 0.54=0.67 .
\end{aligned}
$$

The above two results differ much, and one reason for the latter to be higher than the former could be the enhanced quality of the fertilizer and the technology to apply it hence higher effectiveness of the use of the fertilizer in the later period of time. In this sense it would be more reasonable to use $S_{1975-1999}$ than $S_{1930-1975}$ to 
make a future estimate. However, to be safer, we take the average of the two, $\mathrm{S}=0.35$, as the elasticity to be used. This number means: $1 \%$ increase of fertilizer nutrients would increase the crop yield by $0.035 \%$. This value seems small, but due to the large amount of the fertilizer and so the nutrients it contains (assuming the total N.P.K. nutrients to be only $10 \%$ of the amount of the organic fertilizers produced from this system), its effect to the crop yield increase is significant. As shown in the last row of Table 1, other thing being equal, global crop productions can be increased over 2 times from that of 2012 if this system is implemented worldwide! Even if in only half of the effects, more than $100 \%$ increase of the world crop production is expected. This answers the question whether we can gain an increase of cereals production by one billion tons by 2030 to meet human needs in the world raised in [50]. Furthermore the effect of crop production increase brings other benefits: reducing the demand for land and water supplies.

4.9 In general, a facilitation or direct realization of ecological living environment of human society. The above analyzed benefits, energy savings and emission reductions manifest that the proposed system can well pursue the objectives of ecological farming, carbon sequestration and the mitigation of climate change as advocated by many people [23][30][41].

4.10. Employment creation: Based on an estimate, hundreds to thousands of permanent job positions can be created through both implementing and running this system afterwards for a city of 2.5 million residents as given before. In terms of a whole country, it implies a substantial employment increase.

4.11. Economic benefits and profitability. This is to be seen clearly in the following section.

\section{Economic Feasibility Analysis}

\subsection{Direct (Narrowed-View) Economic Evaluation}

The biogas produced in this system, as stated before, converted into a purity of $95 \%$ methane, is similar to natural gas. Although the price of the natural gas varies for different uses, locations and times (in this paper all the prices and costs are in US dollars), according to the reference [33], we take the relative low price -- $\$ 0.20 / \mathrm{m}^{3}$ -- in consideration. The price of the organic fertilizer produced from this system can be compared with that of compost fertilizer or humus soil on the market. The price of compost could be around or higher than \$200/MT (metric ton), and the price of humus soil could be more than $\$ 300 /$ MT. Here we take the price of the organic fertilizer produced in this system as only $\$ 100 / \mathrm{MT}$. The price for agricultural waste materials (straws, etc.) is taken to be $\$ 10 / \mathrm{MT}$, and the annual operating cost (labor, equipment use and facility maintenance, electricity and all other overheads) to be $\$ 200$ million for the given city of 2.5 million people (the estimation refers to item 12 in Table A). Then, according to the expected output of this system stated in 4.1, we get:

$$
\begin{aligned}
& \text { Net annual income }=\text { biogas revenue }+ \text { net fertilizer revenue }- \text { operation cost } \\
& =\$ 0.2 / \mathrm{m}^{3} * 0.75 \text { billion } \mathrm{m}^{3}+(\$ 100-10) / \mathrm{MT} * 8 \text { million MT }-\$ 200 \text { million } \\
& =\$ 0.67 \text { billion. }
\end{aligned}
$$

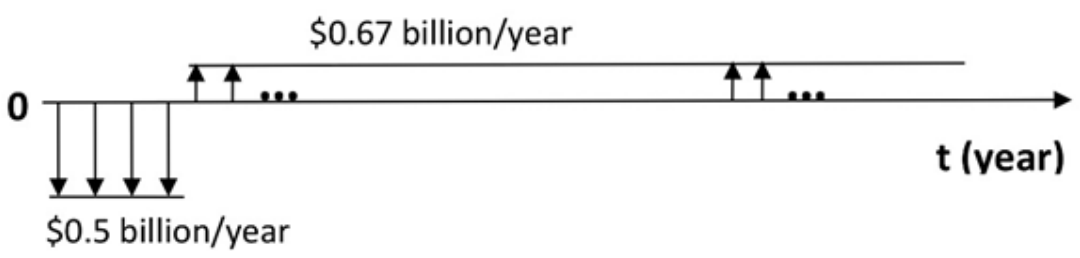

Figure 4. The simplified cash flow

In addition, there could be a windfall income for the entity to implement this system, the CDM (clean development mechanism) carbon-emission reduction credit as defined in the "Kyoto protocol" [27] and the international green market. Indeed, the CDM value can be over $\$ 100$ million dollars a year for the example city even if the CDM price is in $\$ 5 /$ ton only, this is because of up to 20 million tons of $\mathrm{CO}_{2}$ emission reduction annually (Table A, item 10). Globally it would be over 100 billion dollars contribution from this system each year. However, we ignore it here. Other (indirect) gains, such as the value of the vast amount of nutrimental water, and the surplus prices derived from higher quality of grains, fruits or vegetables, etc. are important but ignored here either, so as to make the evaluation more conservative.

The total capital input to implement this system is estimated to be from $\$ 1.5$ billion to $\$ 2.5$ billion for the said city (Table 1, item 11), and we take the median $\$ 2$ billion in the evaluation. The implementation time is taken to 
be 3 to 4 years. Then the simplified cash flow can be shown as in Fig.4: These estimates indicate that the capital return period is less than 4 years in a static evaluation (this is applicable to todays near zero interest rate in many countries) starting from the end of the system implementation, or 7 years from the starting point. On average, take it to be 5 years. In dynamic evaluation and taking the discount rate as $5 \%$, it is less than 10 years to get the full capital returned. In terms of IRR, if the system can be running for 30 years (though it should be longer) before a replacement or major amendment, it could be higher than $30 \%$ even after taxation (at an income tax rate $25 \%$ ). Note at this time we do not consider facility depreciation compensation, which will improve the cash flow but just for simplicity, and minor maintenance cost has been included in the operation cost. This system thus can be recognized as a very profitable project especially considering it is a public-benefit oriented project.

To be more conservative, assume the amount of capital input increases $50 \%$ to $\$ 3$ billion, and the net annual income decreases $50 \%$ to $\$ 0.34$ billion, the static capital return period is still around 10 years only, and dynamically it is less than 20 years at a discount rate of 5\%; and the IRR after tax can be higher than $10 \%$. All of these demonstrate the profitability perspective and the strength of risk resistance of this system.

The above is only a direct economic benefit analysis. In a broader viewpoint, the economic effect of the implementation of this system is even more significant as described below.

\subsection{Broadened Economic Evaluation}

A more general assessment of the economic benefits of the implementation of this system should include its lateral effects and impacts on other related economic sectors or threads. In this regards, for simplicity, we do not give quantitative but mainly qualitative outlines as below:

1) The savings of conventional sewage processing plants, including their construction costs and operating costs, and the savings of the construction and maintenance of numerous septic tanks under most of the buildings in every city.

2) The value in water body clearance, including water de-eutrophication, de-siltation and algae prevention. Notice the huge cost in conventional approaches to build the facilities or infrastructures to fulfill these tasks

In fact, the cost savings described in 1) and 2) above for a particular city can be relatively easily estimated numerically.

3) The value of the savings or replacement of chemical fertilizer plants, their construction and operation costs, energy consumption costs, and more importantly the cost to eliminate (or at least to reduce) the waste water discharge and waste air emissions from these plants thus further improvements of air and water clearance.

4) Cost savings for facilities of water supply and drought resistance in farmland.

5) Cost savings for flood prevention and spillway constructions.

6) Cost savings for rural gas network construction and road constructions.

7) Cost savings and facilitations for rural aquacultures.

8) Cost savings for air purification, especially in reduction of smoking and suspending particles from the use of coal, firewood or crop straws for heating and cooking in countryside due to the energy savings and the biogas production brought by this system. The monetary savings in this regard could never be overestimated.

9) The value of added supply of water and fertilizer to farmers from this system, thus the effects to crop production, food supply and food qualities.

10) The value of reduction of exploitation and consumption of fossil energy sources such as coal, petrol and natural gas, as well as their related geological and environmental damages.

11) The value of improvement and reduction of healthcare and social welfare cost due to the better water and environmental clearance facilitated by this system.

12) The help for employment growth thus the reduction of social security expenses.

13) The value of facilitation of the buildup of ecological settlement and green-economy in general and rural development in particular.

14) The help of promotion of the local manufacturing industry, because of the equipment and facilities needed for this system.

15) Potential increment of export capacity especially in the international green market - the export of this system and the related technology, equipment, consultancy and the like services 
As a conclusion, even if the profit is zero in the narrowed economic evaluation presented in previous part 5.1, this system is still worthwhile to implement because of the above benefits and savings the system could bring up.

\section{Technical Feasibility and Advances}

The above sections have presented the social, economic and environmental feasibilities and benefits of implementing this system. Another question bound to be asked would be the technical feasibility, and furthermore, possible technological advances or innovations.

Generally speaking, there is no major technical or engineering issue preventing the system from being implemented. This is because that the basic functionalities and operations of this system are mainly in distant sewage drainage, biogas and organic fertilizer productions, while all other features and benefits described in the previous sections are established on these three functions, thus currently available technologies can fully support and be used to build up this system. For instance, long-distance drainage of sewage has been realized through different approaches. Note that conventional sewage processing plants have already included the sewage drainage function, though the distance is shorter than that to be covered in this system. The use of sewage to produce biogas has also been practiced for a few hundred years [31], such as the biogas generating pits or pools that we can see today in different places of the world, though these are normally in small capacity and do not assume many benefits and features of this new system described in the previous sections.

A good feature of this system as implied in section 3 is the flexibility of the requirement of technology to build this system. That is, we can start this system from readily available technologies. On the other hand, we can have our innovations and more advanced technology to implement and operate this system more efficiently. The details of the advanced approach invented by the author can be presented in other file, while some general introductions can be given as below.

The first technical advantage of this system is the integration of the conventionally separated functionalities, such as waterway clearance, sewage process, biogas production and fertilizer production as well as their transportation and applications, into an organic and unified program. The mentioned conventional biogas pools could not assume most of these functions, especially for waterway clearance, let alone the integrated efficiencies of other aspects. This integration also implies cost effectiveness.

Secondly, the said integration is not a simple assembly of the separated functions, but certain enhancements and innovations are to be implemented in the new system. For instance, the water de-nutrition, algae prevention and de-siltation will be realized in this system very differently from the conventional approaches and at little cost. For a simple understanding of other technical advances and innovations worked out by the author, we just need to see the shortcomings of the conventional biogas generating pools. Because these pools are usually small in size (mostly in tens or hundreds of $\mathrm{m}^{3}$, seldom in thousands of $\mathrm{m}^{3}$ or larger), it is hard to implement facilities to ensure the water-tightness and air-tightness of the pool, and even to load or replace the contents after a fermentation cycle is over, basically because of cost constraints to implement these facilities. Another example is on hygienic control and epidemic disease preventions, conventional biogas pools could not do well in this regard. Indeed there seems no official rule implemented for this purpose even in developed countries. For instance, the fateful E-coli found in Germany in 2012 were sourced to be from the compost fertilizer of local biogas pools. The new system proposed can effectively overcome these deficiencies or shortcomings with new technologies, which can be presented upon request due to space limitation here.

In addition to the above, the buildup of this system could provide related biologic or biochemical experimental programs commercial applications with a solid, long time lasting, low cost and scalable infrastructure and platform, such that many previous seemingly undoable projects now become financially feasible and easy to implement. For instance, the MFC (microbial fuel cell) study mentioned before (Section 3) can find its wide application with this system. Similarly, in cooperation with this system the value-added utilization of crop straws (to produce ethanol, etc.) can be much easier to implement than before since this system can fully consume the production residuals.

\section{The Approach to Start and Implement the System}

As long as politicians and a governmental administration recognize and support this system based on the technical and economic feasibilities presented in the above sections, the implementation of this system can be started with a pilot project then extended to general deployment. The pilot project is, on one hand, to find out preferable or optimal control parameters for the related sewage drainage and fermentation process to produce biogas and organic fertilizers through engineering experiments. On the other hand it will set up a physical model to guide and monitor the system implementation and operation in large scale thereafter. The main components of the 
pilot project, as a model of the new system, shall consist of one or two process stations in farmland, and a pipeline to drain the sewage from the selected urban point to the process station(s). Each process station will consist of several processing pools. The whole capacity of a station shall be a few up to ten thousand cubic meters, so as to process the amount of sewage of around 10,000 people, considering we are talking about cities of millions residents each. However, there is no problem to implement a smaller pilot project if the stakeholders prefer. The duration of the buildup of the pilot project and the experimental work would be one to two years, and cost to fulfill them would be in only a few million dollars or less, depending on the geographical and other conditions of the implementation location.

After the pilot project is successfully completed and the approach to implement and operate the new system is established, the whole system can be built up in each city, town or megacity according to the local governmental pursuance and plans. The buildup of this system can be in BOT, turn-key or any other arrangement preferred in each place.

The conceptual plan, design and scheme to undertake the pilot project and the related experimental work are readily available from the author once this proposal gets accepted and to be implemented by an interested party.

\section{Conclusions}

It is said [48] that by the year 2025 (not very far from now), 2/3 of the population worldwide will face (fresh) water shortages. Meanwhile, food shortages and energy shortages all over the world have been the topics of human society for centuries. As such, how to protect and ensure the supply of the three most important resources to human beings - clear fresh water, quality food and energy - has become a hot subject in international politics and businesses. Furthermore, the issue of environmental pollution, and thus its control and recovery, has been paid more and more attentions by both politicians and ordinary people. Various practices have also been tried, yet it is still a big challenge to find large scale cost effective and sustainable solutions for the concerned problems. This report presents a systematic solution for water source clearance, renewable energy and organic fertilizer production thus ecological agriculture development, based on the author's multiyear study. This solution is a multi-objective optimization model, and it signifies a realizable approach towards low-carbon economy and circular economy at overall low cost.

In this report the feasibilities, benefits and significances of implementation of the proposed system are demonstrated with a city of 2.5 million residents in environmental, economic, social and technical aspects, and the results and effects are brilliant. Among other things, only in terms of urban sewage and perishable waste process and water clearance, this system provides a package solution once and for all. Other major functions include energy reproduction, emission reduction, farmland fertility improvement, and food security. This system thus promises not only real benefits immediately but more importantly for the future generations of our offspring.

In terms of financial gains and economic benefits, as illustrated before, the investment return from this system is bright as well. Particularly note that this system is basically a public-benefit oriented program, and we know that many public projects are supported (subsidized) directly or indirectly by governments or public funds. This system, however, is not only financially self-supportive, but can even bring big profits. Thus the success of the implementation and operation of this program will significantly change a "commonsense" that environmental protection programs will hinder economic growth. Such sense is held in both developing and developed countries as reflected from the situations exhibiting in various international climate-environment summits.

From a technical perspective, the existing engineering technology is fully capable of performing the buildup of this system. The only thing is that the conventional sewage process approach was not aimed to restore the ecological cycle as depicted in Fig.1 and Fig.3. In other words, the successful development and implementation of this system would be the first such effort and thus an innovative approach towards an effective solution both ecologically and economically.

In view of applicability, this system and its implementation described herein is fully flexible to be applied to either small towns or megacities. As such, there could be a potential market of trillions of dollars brought by this system around the world. This market value can be even larger if the growth of other trades pulled up by this system is taken into account.

In all, this proposed solution does not only meet the requirement of the challenge mentioned before, but is also a contributor to sustainable economy in different aspects.

Of course, to realize the expectations and to practically implement this system, one of the necessary conditions is the recognition and acceptance of this system from the governmental administrations of the interested place(s). 
Another is a good technical preparation. In this sense, a pilot project is suggested to be built up before the deployment and operation of the system in a large scale. The concept, theory, technical framework, implementation methodology, and sketch designs, etc. for either the pilot project or the general deployment of this system, have been deeply studied by the author and available upon request.

\section{Acknowledgement}

Special thanks are to Mr. Clinton Presiloski for his help in English editing.

\section{References}

[1] 2013 World population data sheet. Posted on http://www.prb.org/pdf13/2013-population-data-sheet_eng.pdf

[2] Aelterman, P., Rabaey, K., Clauwaert, P., \& Verstraete, W. (2006). Microbial fuel cells for wastewater treatment. Water Science \& Technology, 54(8), 9-15. https://doi.org/10.2166/wst.2006.702

[3] Ahn, Y., \& Logan, B. E. (2010). Effectiveness of domestic wastewater treatment using microbial fuel cells at ambient and mesophilic temperatures. Bioresource Technology, 101, 469-475. https://doi.org/10.1016/j.biortech.2009.07.039

[4] Ameta, S. K. et al. (2016). Carbon to nitrogen ratio of the combination of feedstocks prepared for composting of parthenium hysterophorus weed. Int. J. Chem. Sci., 14(2), 949-954.

[5] Arable land Wikipedia. Retrieved February 22, 2014 from http://en.wikipedia.org/wiki/Arable_land

[6] ARCHIVED - Appendix B - CO2 Emission Factors. Natural resources Canada, 2013-05-15. On http://www.nrcan.gc.ca/energy/efficiency/industry/technical-info/benchmarking/canadian-steel-industry/5193

[7] Bachmann, N. (2015). Sustainable biogas production in municipal wastewater treatment plants. Technical Brochure, Edited by David Baxter, IEA Bioenergy.

[8] Behera, M., Jana, P. S., \& Ghangrekar, M. (2010). Performance evaluation of low cost microbial fuel cell fabricated using earthen pot with biotic and abiotic cathode. Bioresource Technology, 100(4), 1183-1189. https://doi.org/10.1016/j.biortech.2009.07.089

[9] Benefield, L. (2002, May). "Residential flow rates", Rule Development Committee Issue Research Report Draft, Washington State Department of Health.

[10] BP Statistical Review of Energy 2013. BP, June 2013.

[11] Chang, D., Liao, W. P., \& Chen, S. Y. (1996). Effectiveness of Various Sludge Stabilization and Solidification Methods. Transportation Research Record: Journal of the Transportation Research Board, 1546, 41-52. https://doi.org/10.3141/1546-05

[12] Comparetti, A. et al. (2013). Current state and future of biogas and digestate production. Bulgarian Journal of Agricultural Science, 19(1), 1-14.

[13] Comparison of Fossil Fuels, Biomass and Electricity for Heating Buildings. Retrieved February 26, 2014 from http://www.arca53.dsl.pipex.com/index_files/fuel1.htm

[14] Criteria for the Assessment of Sediment Quality in Quebec and Application Frameworks: Prevention, Dredging and Remediation. Environment Canada and Ministère du Développement durable, de l’Environnement et des Parcs du Québec, 2007.

[15] Current world fertilizer trends and outlook to 2016. Food and Agriculture Organization of the United Nations, Rome, 2012.

[16] Drosg, B. et al. (2015). Nutrient Recovery by Biogas Digestate Processing, IEA Bioenergy Task 37 report, June 2015.

[17] Fan, Y. T. et al. (2006). Efficient conversion of wheat straw wastes into biohydrogen gas by cow dung compost. Bioresource Technology, 97(3), 500-505. http://dx.doi.org/10.1016/j.biortech.2005.02.049

[18] FAO Agri-Environmental Statistics: World Crops Production of 2012, Food and Agriculture Organization of the United Nations. Retrieved from http://www.fao.org/

[19] Fertilizer consumption (kilograms per hectare arable land), World Development Indicators, World Bank. Retrieved February 16, 2014, from http://search.worldbank.org/

[20] Food, land, population, and the U.S. economy. Retrieved December 16, 2013, from http://www.carryingcapacity.org/resources.html 
[21] Gude, V. G. (2016). Wastewater treatment in microbial fuel cells - an overview. Journal of Cleaner Production, 122(20), 287-307. https://doi.org/10.1016/j.jclepro.2016.02.022

[22] Heat values of various fuels. Retrieved from http://www.world-nuclear.org/information-library/ facts-and-figures/heat-values-of-various-fuels.aspx

[23] Hepperly, P., Setboonsarng, S. (2015). Carbon Sequestration in Organic Agriculture and Climate Change: A Path to a Brighter Future. In S. Setboonsarng, \& A. Markandya (Eds.), Organic Agriculture and Post-2015 Development Goals: Building on the Comparative Advantage of Poor Farmers (pp. 293-322). Manila.

[24] IFADATA, world fertilizer consumptions in 2011. Retrieved February 26, 2014 from http://www.fertilizer.org/HomePage/STATISTICS

[25] Investors manual for energy efficiency. Confederation of Indian Industry - Energy Management Cell. Retrieved May, 2017, from http://www.ireda.gov.in/writereaddata/IREDA-InvestorManual.pdf

[26] Kelessidis, A., \& Stasinakis, A. S. (2012). Comparative study of the methods used for treatment and final disposal of sewage sludge in European countries. Waste Management, 32, 1186-1195. https://doi.org/10.1016/j.wasman.2012.01.012

[27] Kyoto Protocol to the United Nations Framework Convention on Climate Change. The United Nations, 1988. Retrieved from http://unfccc.int/resource/docs/convkp/kpeng.pdf

[28] Lake Winnipeg most threatened in world in 2013. CBC News. Retrieved February 5, 2013, from www.cbc.ca

[29] List of countries by irrigated land area. Wikipedia. Retrieved February 23, 2014 from http://en.wikipedia.org/wiki/List_of_countries_by_irrigated_land_area,

[30] Magdoff, F. (2007). Ecological agriculture: Principles, practices, and constraints. Renewable Agriculture and Food Systems, 22(2), 109-117. https://doi.org/10.1017/S1742170507001846

[31] McCabe, J., \& Eckenfelder, W. (Eds.). (1957). Biological Treatment of Sewage and Industrial Wastes (Vol. 2). New York: Reinbold Publishing.

[32] Mitchell, C. C. (2008). Nutrient Content of Fertilizer Materials. 2008 by the Alabama Cooperative Extension System.

[33] Natural Gas Prices, monthly. From http://www.cga.ca/wp-content/uploads/2011/02/Chart-3-Natural-Gas-Price21.pdf

[34] Oscar, A., \& Maynard, D. N. (1980). Knott's Handbook for Vegetable Growers (2nd ed.).

[35] Paull, J., \& Hennig, B. (2016). Atlas of Organics: Four Maps of the World of Organic Agriculture. Journal of Organics, 3(1), 25-32.

[36] Phylipsen, D., Einstein, D., \& Martin, N. (2000, April). Energy Use and Energy Intensity of the U.S. Chemical Industry Ernst Worrell, Energy Analysis Department, Environmental Energy Technologies Division, Ernest Orlando Lawrence Berkeley National Laboratory.

[37] Potter, M. C. (1911). Electrical effects accompanying the decomposition of organic compounds. Royal Society (Formerly Proceedings of the Royal Society) B, 84, p260-276. https://doi.org/10.1098/rspb.1911.0073

[38] Prasad, M., Lee, A., \& Gaffney, M. T. (2012). A detailed chemical and nutrient characterization of Compost and Digestate including comparative releases of Nitrogen and Phosphorus. rx3 rethink recycle remake 2012.

[39] Quantification of Feedstocks for Anaerobic Digestion Group Report. A Northern Ireland Case Study Appendix 3.1, Biogas Action Plan for Northern Ireland, February 2014.

[40] Sakamoto, T. et al. (2012). A. Direct ethanol production from hemicellulosic materials of rice straw by use of an engineered yeast strain codisplaying three types of hemicellulolytic enzymes on the surface of xylose-utilizing Saccharomyces cerevisiae cells. Journal of Biotechnol, 158, 203-210. https://doi.org/10.1016/j.jbiotec.2011.06.025

[41] Scialabba, N., \& Mu"ller-Lindenlauf, M. (n.d.). Organic agriculture and climate change. Renewable Agriculture and Food Systems, 25(2), 158-169.

[42] Soh, K. G. (2001). Global Supply and Demand for Urea. Mitco Marketing \& Trading Forum 2001, Bangi, Malaysia.

[43] Technical Report - Green Lake Alum Treatment Study. Prepared for Seattle Department of Parks and 
Recreation, Prepared by Herrera Environmental Consultants, June 5, 2003.

[44] von Münch, E., \& Winker, M. (2011). Technology review of urine diversion components. Gesellschaft für Internationale Zusammenarbeit (GIZ) GmbH.

[45] Wang, G. et al. (2016). Persistent sulfate Formation from London Fog to Chinese haze. Proceedings of the National Academy of Sciences of the United States of America, Vol. 113, Nov. 29, pp13630-13635. https://doi.org/10.1073/pnas.1616540113

[46] Wang, X. et al. (2012). Optimizing feeding composition and carbon-nitrogen ratios for improved methane yield during anaerobic co-digestion of dairy, chicken manure and wheat straw. Bioresource Technology, 120, 78-83. https://doi.org/10.1016/j.biortech.2012.06.058

[47] Wastewater Flow Estimation and Servicing Guidelines. Water and Waste Department, Winnipeg, July 25, 2016, from winnipeg.ca/waterandwaste/dept/wastewaterFlow.stm.

[48] Water scarcity could be liquid gold for investors. Reported by Rachel Koning Beals, Market Watch, March 01, 2013. Retrieved March 3, 2013, from http://www.marketwatch.com/

[49] Weiland, P. (2010). Biogas production: current state and perspectives. Appl Microbiol Biotechnol, 85(4), $849-60$.

[50] World agriculture towards 2015/2030. Food and Agriculture Organization of the United Nations, Rome, 2002. https://doi.org/10.1007/s00253-009-2246-7

[51] Zhang, H. (2010). Sludge treatment to increase biogas production. Trita-LWR Degree Project 10-20, Sweden.

[52] Ministry of Environmental Protection: Straw burning is the principal cause of toxic haze in northeast China, the contribution rate is nearly $55 \%$. Retrieved from http://www.chinadaily.com.cn/micro-reading/china/2015-11-18/content_14339918.html 


\section{Appendix}

\section{The methods and calculations of the estimates}

Table A below provides the methods and calculations of the estimates presented in the main text of this paper. A main purpose of this paper is to let different readers have a general understanding of the basic ideas and the benefits to be brought up by the proposed system, and so is this part. That is, this appendix presents the related high level concepts, measures and parameters to be used in the estimations. More information on how and where these measures and parameters come from can be referred from but not limited to the references given in each item of the table.

In Table A, column $\mathrm{C}$ shows the estimates of different benefits or costs of the system built in the example city based on the descriptions and formulas given in column B, while column D is the estimates taken and presented in the main text (with page number given). As can be seen from the table, most of the taken estimates are far more conservative than that from column C. However, all the estimates presented in this paper are conceptual and indicative only, they may vary substantially in different real project estimations.

Table A. Methods and calculations of the estimates

\begin{tabular}{|c|c|c|c|}
\hline $\mathbf{A}$ & B & C & D \\
\hline Items & Descriptions and formulas & Basic Estimates & $\begin{array}{c}\text { Estimates } \\
\text { Taken }\end{array}$ \\
\hline 1 & The example city population $\mathrm{P}=2.5 * 10^{6}$ & & \\
\hline 2 & $\begin{array}{l}\text { Sewage volume, } \mathrm{V}\left(\mathrm{m}^{3}\right) \text { : } \\
\quad \text { Sewage discharge rate [9][47] } \mathrm{v}=0.2 \sim 0.28 \mathrm{~m}^{3} \text { per capita per day, the } \\
\text { annual total discharge of the example city } \mathrm{V}=\mathrm{V} * \mathrm{P} * 365 \text {. }\end{array}$ & $(180 \sim 250) * 10^{6}$ & $\begin{array}{l}100 * 10^{6} \\
\text { (p5) }\end{array}$ \\
\hline 3 & $\begin{array}{l}\text { Organic fertilizer output (dry state), } \mathrm{F} \text { (metric ton, MT): } \\
\text { Since the water content is large in urban sewage flow, the wet } \\
\text { fermentation approach shall be used, and the proper solid content [4][46][49] } \\
\text { for biogas production is } \mathrm{f}=10 \sim 15 \% \text {. Take } \mathrm{f}=12 \% \text {, the total solid (TS, or dry } \\
\text { matter called alternatively) } \mathrm{F}=\mathrm{V} * 12 \%\end{array}$ & $(20 \sim 30) * 10^{6}$ & $\begin{array}{l}8 * 10^{6} \\
(\mathrm{p} 5)\end{array}$ \\
\hline 4 & $\begin{array}{l}\text { Nitrogen availability and equivalent urea gains, } \mathrm{U}(\mathrm{MT}) \text { : } \\
\text { Reports on the total nitrogen available from the biogas digestates vary } \\
\text { greatly in the literature, from } 2 \% \text { to } 17 \%[16][32][34][38] \text {. Since the proposed } \\
\text { system shall absorb any digestible organic feedstock, it is reasonable to take } \\
\text { the average reported value. Indeed, here we take it } 7 \% \text {, below the average, and } \\
\text { the total nitrogen } \mathrm{TN}=\mathrm{F} * 7 \% \text {. } \\
\text { Notice that there is another big amount of nitrogen from various urines } \\
\text { blended in the sewage }[44] \text {. However, we ignore it here. } \\
\text { Then the equivalent amount of urea fertilizer }(\mathrm{N}=46 \%) \text { can be obtained } \\
\text { from the system: } \mathrm{U}=\mathrm{TN} / 46 \%=\mathrm{F} * 15 \% \text {. }\end{array}$ & $(3 \sim 4.5) * 10^{6}$ & $\begin{array}{l}1 * 10^{6} \\
(\mathrm{p} 5)\end{array}$ \\
\hline
\end{tabular}


Table A. Methods and calculations of the estimates (cont.)

\begin{tabular}{|c|c|c|c|}
\hline $\mathbf{A}$ & $\mathbf{B}$ & $\mathbf{C}$ & $\mathbf{D}$ \\
\hline Items & Description and formulas & Basic Estimates & $\begin{array}{l}\text { Estimates } \\
\text { Taken }\end{array}$ \\
\hline 5 & $\begin{array}{l}\text { Biogas thus methane production. } \mathrm{G}\left(\mathrm{m}^{3}\right) \\
\text { Different feedstock has different biogas yield. For simplicity, we divide } \\
\text { the feedstocks into two categories, nitrogen rich (e.g., sewage sludge, meal } \\
\text { wastes, etc.), named as } \mathrm{T} 1 \text {, and } \mathrm{T} 2 \text { carbon rich (e.g., corns \& straws), } \mathrm{T} 1+\mathrm{T} 2 \\
=\mathrm{F} \text {. For a good biogas production, the feedstocks should be mixed with a } \\
\text { proper carbon and nitrogen ratio [4][12][46][51], C:N }=20 \sim 30: 1 \text {. From } \\
{[4][34] \text {, this ratio can be achieved with } \mathrm{t} 1=\mathrm{T} 1 / \mathrm{F}=0.3 \text { and } \mathrm{t} 2=\mathrm{T} 2 / \mathrm{F}=0.7 \text {. }} \\
\text { From [38][40][41][49], the biogas yield from } \mathrm{T} 1 \text { can be taken as } \mathrm{r} 1=260 \\
\mathrm{~m}^{3} / \mathrm{MT} \text { and from } \mathrm{T} 2 \text { as } \mathrm{r} 2=420 \mathrm{~m}^{3} / \mathrm{MT} \text {, all in dry matter. Then the total biogas } \\
\text { production: } \\
\quad \mathrm{B}=\mathrm{F} * \mathrm{t} 1 * \mathrm{r} 1+\mathrm{F} * \mathrm{t} 2 * \mathrm{r} 2=\mathrm{F}(0.3 * 260+0.7 * 420)=\mathrm{F} * 372 \text {. } \\
\text { From the above literatures, methane makes } 50 \% \text { to } 75 \% \text { of the biogas. } \\
\text { Here take it as } 60 \% \text {. To be comparable with natural gas which is of } 95 \% \\
\text { methane, then the total methane yields: } \\
\quad \mathrm{G}=\mathrm{B} * 60 \% / 95 \%=\mathrm{F} * 372 * 63.2 \%=\mathrm{F} * 235 \text {. }\end{array}$ & $(0.71 \sim 1.1) * 10^{9}$ & $\begin{array}{ll}0.75 & * 10^{9} \\
(\mathrm{p} 5) & \end{array}$ \\
\hline 6 & $\begin{array}{l}\text { From } \mathrm{U} \text {, the equivalent natural gas }(\mathrm{NG}) \text { savings, } \mathrm{Q}\left(\mathrm{m}^{3}\right) \\
\text { The urea gained from the proposed system means an energy saving to } \\
\text { produce the urea conventionally. The urea production involves two main } \\
\text { stages: (a) ammonia synthetization and then (b) urea synthetization. Stage (a) } \\
\text { consumes about } 80 \% \text { of the total energy. } \\
\text { From [25][36], the total energy consumption to produce } 1 \mathrm{MT} \text { of urea } \\
\text { varies from } 5.7 \mathrm{GCal}\left(10^{9} \mathrm{Cal}\right) \text { to } 13 \mathrm{GCal} \text {. Here again we take a low number, } \\
6.0 \mathrm{GCal} \text { per MT of urea, in the estimation, where } \\
\mathrm{q} 1=0.58 * 10^{3} \mathrm{~m}^{3} \text { natural gas carrying about } 4.8 \mathrm{GCal} \text { to be directly used } \\
\left.\text { in stage (a) (take the } \mathrm{NG} \text { heat value } \mathrm{h}=8.2 \mathrm{MCal} / \mathrm{m}^{3}[12][52]\right) \text {. } \\
\text { Suppose the rest } 1.2 \mathrm{GCal}(\mathrm{electric} \text { power) is fully generated from } \\
\text { burning natural gas, and consider the efficiency to be } 0.33 \text { [22], then, } \\
\mathrm{q} 2=1.2 * 10^{3} / \mathrm{h} / 0.33=0.44 * 10^{3} \mathrm{~m}^{3} \text { natural gas is needed. } \\
\text { The total volume of natural gas required to produce the corresponding } \\
\text { urea } \mathrm{U} \text { is then: } \\
\mathrm{Q}=(\mathrm{q} 1+\mathrm{q} 2) * \mathrm{U}=(0.58+0.44) * 10^{3} * \mathrm{U}=1.02 * 10^{3} \mathrm{U} \text {. }\end{array}$ & $(3.06 \sim 4.6)$ & $\begin{array}{l}1.75 * 10^{9} \\
\text { (From the } \\
\text { difference } \\
\text { between } \\
\text { row } 7 \text { and } \\
8 \text {, column } 2 \\
\text { in Table 1.) }\end{array}$ \\
\hline 7 & $\begin{array}{l}\text { The total natural gas saving (or gain in other word, from item } 5 \text { and } 6 \text { ), } \\
\qquad \mathrm{TG}=\mathrm{G}+\mathrm{Q}\end{array}$ & $(3.8 \sim 5.7) * 10^{9}$ & $\begin{array}{l}2.5^{*} 10^{9} \\
\text { (p6) }\end{array}$ \\
\hline 8 & $\begin{array}{l}\text { The total equivalent coal saving converted from natural gas, TC (MT): } \\
\qquad \mathrm{TC}=\mathrm{TG} * 1.27 * 10^{-3} \\
\text { (the conversion rate refers to note } 6 \text { in Table } 1 \text {, and same to below) }\end{array}$ & $(4.8 \sim 7.2) * 10^{6}$ & $\begin{array}{l}2.86 * 10^{9} \\
=2.25 * 10^{9} \\
\text { toe } \quad(\text { Table } \\
1)\end{array}$ \\
\hline 9 & $\begin{array}{l}\text { The total equivalent oil saving converted from natural gas, TO (MT) } \\
\qquad \mathrm{TO}=\mathrm{TG} * 0.9 * 10^{-3}\end{array}$ & $(3.4 \sim 5.1) * 10^{6}$ & $\begin{array}{l}2.25 * 10^{9} \\
(\text { Table } 1)\end{array}$ \\
\hline
\end{tabular}


Table A. Methods and calculations of the estimates (cont.)

\begin{tabular}{|c|c|c|c|c|c|c|}
\hline $\mathbf{A}$ & \multicolumn{4}{|c|}{$\mathbf{B}$} & $\mathbf{C}$ & D \\
\hline Items & \multicolumn{4}{|c|}{ Description and formulas } & $\begin{array}{c}\text { Basic } \\
\text { Estimates }\end{array}$ & $\begin{array}{c}\text { Estimates } \\
\text { Taken }\end{array}$ \\
\hline 10 & \multicolumn{4}{|c|}{ 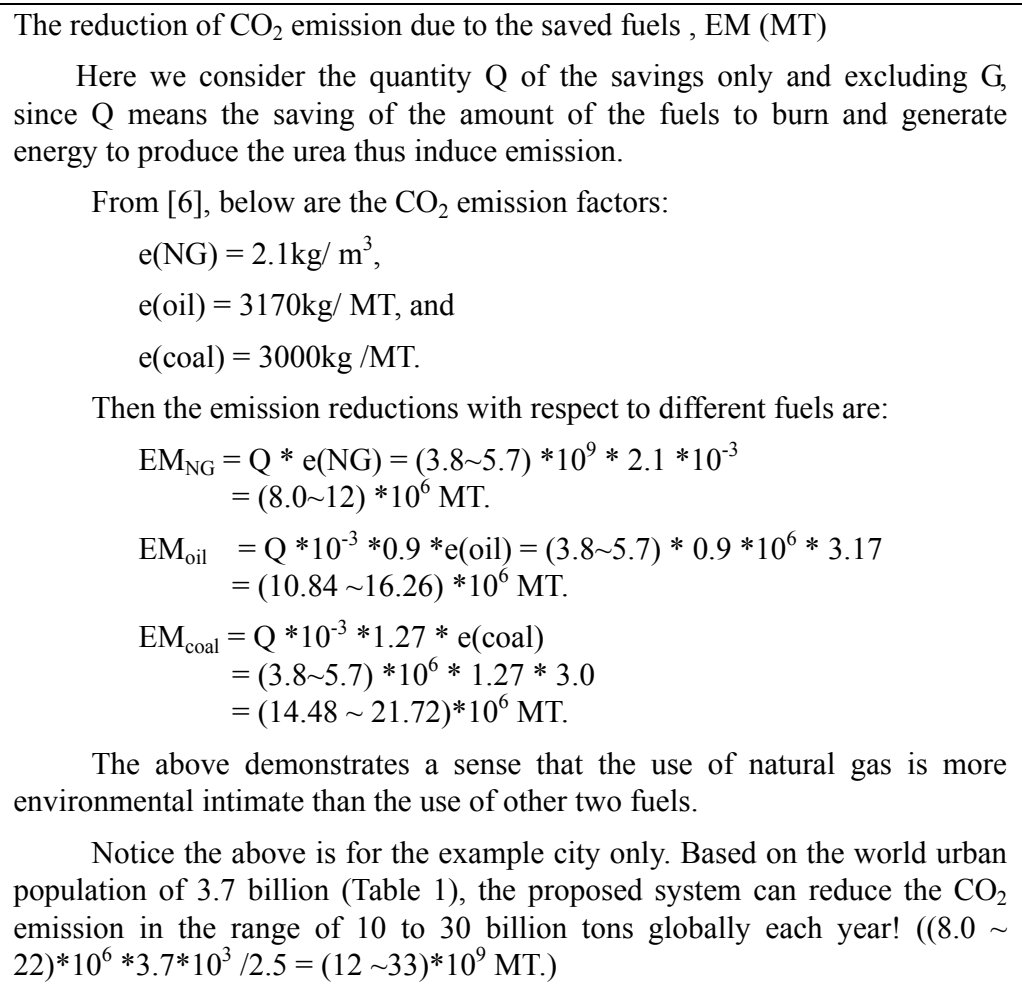 } & $(8.0 \sim 22) * 10^{6}$ & $\begin{array}{l}\text { up to } 20 \\
\text { million } \\
\text { tons for the } \\
\text { example } \\
\text { city (p9), } \\
\text { up to } 30 \\
\text { billion tons } \\
\text { globally } \\
\text { (p6) }\end{array}$ \\
\hline 11 & \multicolumn{4}{|c|}{ 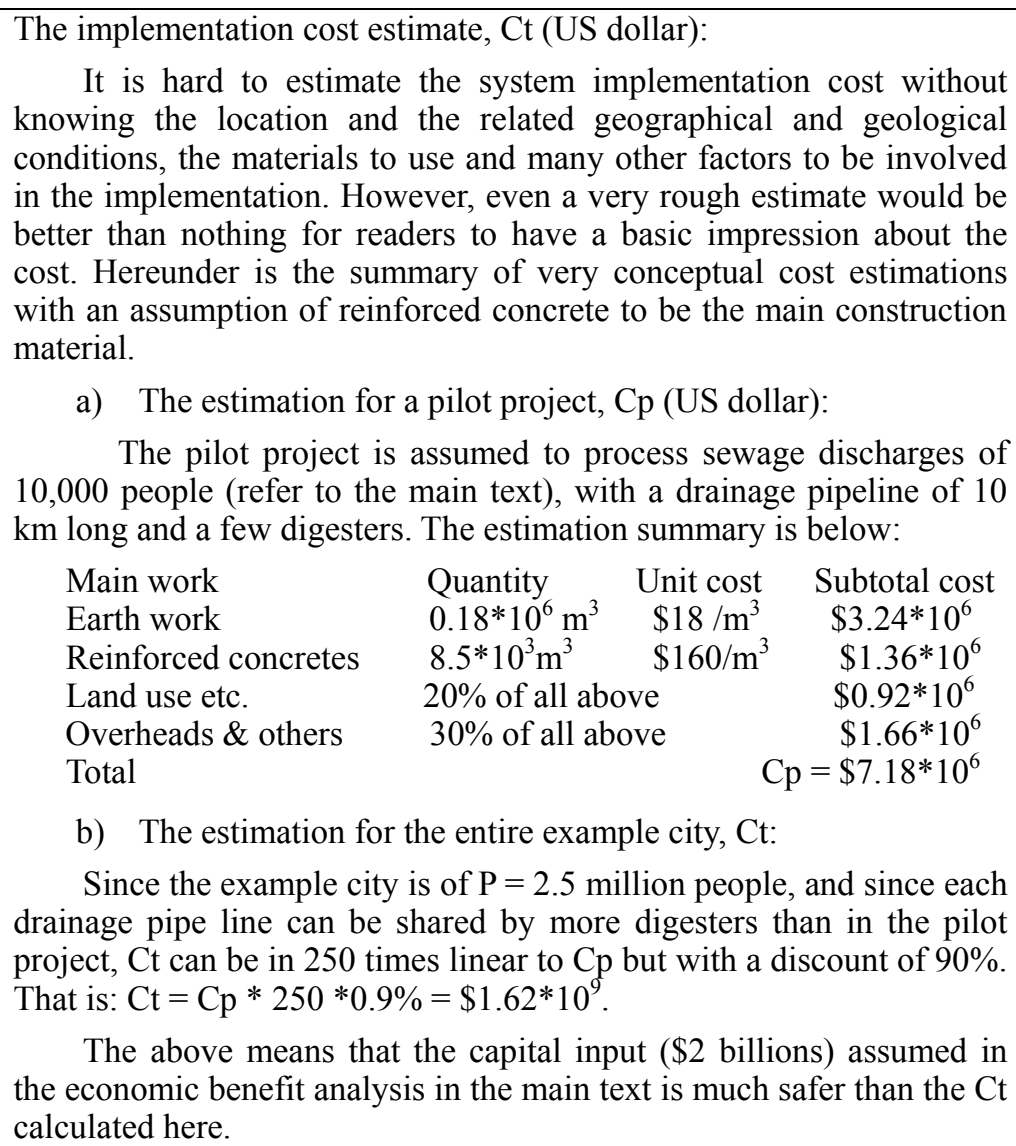 } & $\$ 1.62$ billon & $\begin{array}{l}2 \text { billion } \\
\text { (p9) }\end{array}$ \\
\hline
\end{tabular}


Table A. Methods and calculations of the estimates (cont.)

\begin{tabular}{|c|c|c|c|}
\hline$\overline{\mathbf{A}}$ & B & $\mathrm{C}$ & $\mathbf{D}$ \\
\hline Items & Description and formulas & $\begin{array}{c}\text { Basic } \\
\text { Estimates }\end{array}$ & $\begin{array}{c}\text { Estimates } \\
\text { Taken }\end{array}$ \\
\hline 12 & $\begin{array}{l}\text { The annual operation cost estimate, Cx (US dollars): } \\
\text { Follow the above and assume } 250 \text { sewage treatment stations of } \\
\text { the example city. } \\
\text { a) The annual operation cost of an station Cy: } \\
\text { Suppose each station needs a manager, } 6 \text { different } \\
\text { engineers/technicians but each of them should work for a few (take it } \\
\text { 3) stations, that is, in average two professionals for each station, and } 6 \\
\text { operational workers. Cy is then estimated as below: } \\
\text { Item } \\
\text { Salaries } \\
\text { Equipment use and maintenance } \\
\text { Electricity, fuels, etc. } \\
\text { Overheads \& others } \\
\text { Total } \\
\text { b) The entire example city's Cx: } \\
\text { Cx }=\text { Cy } * 250=\$ 0.79 \text { million } * 250=\$ 150,000 \\
\end{array}$ & \$197 million. & $\begin{array}{l}\$ 200 \\
\text { million } \\
(\mathrm{P} 9) .\end{array}$ \\
\hline
\end{tabular}

\section{Copyrights}

Copyright for this article is retained by the author(s), with first publication rights granted to the journal.

This is an open-access article distributed under the terms and conditions of the Creative Commons Attribution license (http://creativecommons.org/licenses/by/4.0/). 